\title{
Kentsel Yoksulluk Tartışmalarının Kavramsal Kalibrasyonu: Wacquant ve İleri Marjinallik
}

\author{
Anıl Mühürdaroğlu \\ Trakya Üniversitesi
}

$\ddot{O ̈ z}_{z}$

Gelişmiş ülkelerdeki endüstrisizleşme sürecini takiben metropollerde istihdam imkanına büyük oranda sahip olmayan geniş kitlelerin varlığı 1980'li yıllarla birlikte gözle görünür hale geldi. Kentleşme yazını bu durumu, kent merkezlerinde sıkışmış geniş yoksul mahalleler konusunda gelişmiş bir araştırma geleneğine sahip olan Amerikan sosyolojisinin sunduğu araçlardan faydalanarak çözümleme yoluna gitti. Loic Wacquant'in kentsel yoksulluk üzerine çalışmaya başladığı dönemlerde Avrupa kentlerinde yoksulluğun dönüşümü büyük oranda getto ve sinıf-altı gibi Amerikan menşeili kavramlar üzerinden tartışılmaktaydı. Wacquant karşılaştırmalı bir bakış açısı önererek gelişmiş ülke kentlerinin Amerikanlaşacağı yönündeki argümanları reddetmiş, ayrıca Amerikan sosyolojisinin kendi içerisinde yoksulluğu kavramsallaştırma tarzının büyük oranda Amerikan siyah gettosunda yaşayanları damgalayııı bir nitelik taşıdığını ortaya koymaya çalışmıştır. Wacquant'ın kent sosyolojisine yönelik temel katkısı siyah gettosuna dair değerlendirmelerinde ortaya çıkar. Amerikan sosyoloji geleneğinin yoksulluk olgusunu siyasal içerimlerinden sıyırarak teknik bir hizmet sunumu sorunu olarak ele alma alışkanlığı karşısında Wacquant, devletin ayrımcılık olgusuna doğrudan dahlini göstermeyi hedefleyen bir yaklaşım önerir. Wacquant'a göre ABD'de devlet yoksulluk meselesini bir yandan yeni ekonomik yaptlanma içerisinde istihdam imkânı bulamayan siyah nüfusun gettolarda daha fazla yoğunlaşmalarına yönelik uygulamalarla, öte yandan denetim ve cezalandırma uygulamaların daha da genişletip sıkılaştırmak suretiyle ele almıştır. Bu çalışmada Wacquant'ın kentleşme literatürüne dair genel değelendirmeleri ile Amerikan kent sosyolojisinin getto olgusuna bakışına dair eleştirileri ele alınacak, ardından kendi alternatif formülasyonu eleştirel olarak değgerlendirilecektir.

Anahtar kelimeler: Getto, ileri marjinallik, kentsel yoksulluk, sinff-altı 


\title{
Conceptual Recalibration of the Debates on Urban Poverty: Wacquant and Advanced Marginality
}

\author{
Anıl Mühürdaroğlu \\ Trakya University
}

\begin{abstract}
Following the de-industrialization process in advanced countries, the existence of populations which were largely excluded from employment opportunities had become more and more apparent by 1980ies. Urbanization literature tried to understand the ongoing process by using the instruments of American sociology which had an advanced tradition of research on extensive neighborhoods of poverty in the so-called inner city. Discussions on the transformation of urban poverty in European cities had been largely filled with American-originated concepts like ghetto and underclass during the periods when Loic Wacquant started his research on urban poverty. Wacquant offered a comparative perspective and repudiated the arguments which were based on the assumption of the Americanization of European cities. In addition, he argued that conceptualization of urban poverty in American sociology mostly serves for the stigmatization of black ghetto residents. Wacquant's main contribution is his studies on the black ghetto. Standing against the tendency of the American sociological tradition to strip off the political implications of poverty and presenting it as a technical problem of service provision, Wacquant offers a perspective which focuses on the direct involvement of the state in segregation. According to Wacquant, the state in the US tried to deal with poverty by increasing the concentration of black population who have little or no employment opportunity in the restructured economy in ghettos on the one hand, and extending and tightening the instruments of control and punishment on the other. In this study, Wacquant's general evaluations on the literature on urbanization and his critique of American sociology's approach to the ghetto phenomenon will be introduced and his own formulation on this issue will be critically evaluated.
\end{abstract}

Keywords: Ghetto, advanced marginality, urban poverty, underclass

idealkent @ Kent Araştırmaları Dergisi (Journal of Urban Studies)

http://idealkentdergisi.com

Geliş Tarihi Received Date: 16.02.2019 Kabul Tarihi Accepted Date: 11.04.2019 


\section{Giriş}

1970'ler sonrasında Fordist birikim rejiminden post-Fordizme geçiş sürecinin üretim süreci ve istihdam yapısındaki yansımaları ve buna paralel 'devletin mali krizi' olarak tanımlanan süreçle birlikte refah devleti uygulamalarındaki dönüşümün 'yeni kentsel yoksulluk' olarak tanımlanan bir fenomene kaynaklık ettiği tartışmaları 1980'lerin ikinci yarısı ve 1990'lar kentleşme literatüründe genişçe yer almıştı. Mingione, International Journal of Urban and Regional Research dergisinin konu hakkındaki bir özel sayısının girişinde sanayi toplumlarında yaşanan dönüşümün yarattığı yeni kentsel yoksulluğun belirteçlerini şöyle sıralar: (1) dilencilik ve evsizliğin yaygınlaşması; (2) özellikle dezavantajlı gruplar arasında işsizlik ve düşük ücretli istihdamın artışı; (3) genç çetecilerin ve çocukların içerisinde yer aldığı sokak suçlarındaki artış; (4) kent merkezlerinde psikolojik rahatsızlığ olan kimsesiz kişilerin giderek daha fazla gözlenmesi; ve (5) köhne yapılardan oluşan geniş yapılı alanların oluşması. Mingione bu manzaranın yanı sıra bütün büyük kentlerde zenginlik içerisinde yaşanan kısımlarla "kronik yoksulluk ve marjinalleşmenin", isyan ve şiddet olaylarının yaygın olduğu gettolar arasında bölünerek 'Amerikanlaşacağı' yönünde bir kaygının alttan alta yaygınlaştığını ifade eder (Mingione, 1993:324). Getto kavramının kullanılma biçimi ve Avrupa'da kentlerin Amerikanlaşacağı yönündeki bu kaygı ve tartışmalar, aşağıda ele alınacağı üzere, Wacquant'ın kent sosyolojisine dair geliştirdiği eleştirilerin başında gelmektedir.

Metropollerde yüksek gelir gruplarının yaşadığı mekânlarla "gettolar" arasında keskinleştiği ifade edilen ayrışma, 'ikili kent' veya 'bölünmüş kent' gibi kavramlarda ifadesini buldu. Örneğin Mollenkopf ve Castells'e göre ikili kent olgusu "ekonomik ve ırksal kutuplaşmanın" giderek keskinleştiği New York kentinin basın ve edebiyattaki temsilinde yer alan çekici bir metafor olmanın ötesine geçmişti. Özellikle New York'un gündeminde öne çıkan bir takım şiddet olayları sonucu artan ve New York'un ilk (ve bugüne kadar tek) Afrikalı-Amerikalı belediye başkanı olan David Dinkins'in 1990'da göreve gelmesiyle yeni bir boyut kazanan urksal gerilim ile birlikte ikili kent olgusu sosyal bilimler açısından da önemli bir olguydu artık (Mollenkopf ve Castells, 1991:3-5). Gettolaşma ve yeni kentsel yoksulluk olgusu Avrupa bağlamında en yoğun olarak, Sassen'in New 
York ve Tokyo ile birlikte küresel dünyanın üçüncü finansal merkezi olarak ilan ettiği (Sassen, 1991, s. 5) Londra üzerinden tartışıldı. Ekonomik yeniden-yapılanmanın siyasa-yapım süreçlerine yansımasını ifade eden 'yeni sağ' kavramı sıklıkla bu dönüşüm sürecinde sırasıyla Amerika ve İngiltere' de başkan ve başbakan konumunda olan Ronald Reagan ve Margaret Thatcher isimleri ile birlikte anıliyordu. Bu anlamda kentleşme yazınında ekonomik yeniden-yapılanmanın mekâna yansımasına dair tartışmalar büyük oranda 'sanayisizleşme' süreci, uluslararası sermayeyi çekmeye çalışan kentler arasındaki rekabet, devlet ve yerel siyasetin işleyiş mekanizması ve kentsel planlama, kamu-özel ortaklıkları, kent merkezlerinin dönüşümü, esnek birikim rejiminin sınıfsal yapı ve çalışma üzerindeki etkisi, yoksulluk, sosyal dişlanma ve yeni kentsel sosyal hareketler bağlamında New York ve Londra örnekleri üzerinden Amerika ve İngiltere arasında yapılan karşılaştırmaların sunduğu kavramsal çerçeve ve veriler kullanılarak tartışıld. ${ }^{1}$

'Yeni uluslararası iş bölümü' çerçevesinde yaşanan ekonomik dönüşümün yapısal anlamda Avrupa ve Amerika'daki metropollerde birbirine benzer sonuçlar doğuracağı görüşü, 1980'ler ve 1990'larda küreselleşmenin aynılaştırıcı etkisine dair tartışmaların yoğunluğu göz önünde bulundurulduğunda şaşırtıcı değildi. Öte yandan, 1970'ler sonrasında kentlerde yaşanan dönüşümü ve bunu tetikleyen etkenleri tasvir etme girişimleri farklı paradigmaların kavramsal setlerinin birbirine karışmasını beraberinde getirdi. Bu karmaşa ekonomik yeniden-yapılanmanın çalışma ve kolektif tüketim mallarının sunumu gibi alanlardaki olumsuz etkilerini eleştirenlerle bu yeniden yapılanma sürecinde kentlerin yeni rolüne dair tespitleri küresel ekonomide başarılı olmanın reçetesi olarak görüp söz konusu dönüşümü kutlayan yaklaşımların aynı kavramlar çerçevesinde görüşlerini dile getirmesine neden oldu. Örneğin yeni kentsel yoksulluğu yaratan önemli faktörlerden birisi olarak görünen emek piyasalarının dönüşümü süreci 'esneklik' kavramı üzerinden tartışılmaktaydı. Ancak kavramın kullanılma biçimi paradigmalar arasında farklılık gösteriyordu.

\footnotetext{
${ }^{1}$ İngiltere'de kentlerin yapılanması ile ilgili olarak bkz. Imrie ve Thomas (der.) (1999), Allmendinger ve Thomas (der.) (1998), Oatley (der.) (1998), Hamnet (2003). İngiltere ve Amerika arasında karşılaştırmalar için bkz. Fainstein (vd.) (der.) (1992), Barnekov (vd.) (1989). Avrupa'da kentlerin dönüşümüne dair değerlendirmeler için bkz. Szelenyi (der.) (1984), Bagnasco ve Le Galés (der.) (2000), Le Galés (2002), Newman ve Thornley (1996).
} 
Dönemin siyasal paradigmasına adını veren ve Wacquant'ın da üzerinde durduğu neoliberalizmin ekonomik alandaki öncüleri, emek piyasalarının 'esnek olmayan' yapısına yönelik eleştirilere dayanıyordu. Buna göre gelişmiş ülkelerdeki güçlü sendikalar bu yapının oluşmasına neden olmakta, ücret farklılıklarının düşük olması emeğin mobilitesini sınırlandırmakta, yüksek ücretler işsizliğe neden olmakta, dahası, sosyal güvenlik mekanizmaları gönüllü işsizliği teşvik etmekteydi. Öte yandan, üretim alanındaki dönüşümü 'esnek uzmanlaşma' üzerinden tanımlayan yaklaşımlar, neoliberal yaklaşımın düzenleyici mekanizmaların ortadan kalkmasına yönelik taleplerinin aksine, uzun-vadede başarı için işçi- işveren ve şirketler ile taşeronlar arasında belli bir güven ve işbirliğine, ayrıca teknolojik enformasyon ve yetişmiş işgücü gibi girdileri sağlayacak olan "kolektif kurumlara" ihtiyaç olduğunu ifade ediyorlardı (Marshall, 1999, ss. 202-203; Hirst ve Zeitlin, 1991, s. 7). Esneklik kavramı aynı zamanda istihdam yapısında bu dönemde yaşanan dönüşümü ve bir tarafta hizmet sektörünün ön plana çıkmaya başladığı gelişmiş ülkelerde güvencesiz, yarızamanlı işlerin artışını, öte yandan ağır sanayinin taşındığı az gelişmiş ülkelerde sendikasız ve geleceği belirsiz şekilde çalışan işçilerin durumunu tanımlamak için kullanıldı. ${ }^{2}$

Bu tartışmalar 1970'ler öncesi dönemin nasıl tanımlanması gerektiğinden 1970'lerle birlikte yaşanan dönüşümlerin hangi dinamiklerle açıklanabileceğine kadar pek çok noktada farklılaşsa bile, bu tartışmalar kentleşme yazınına esnek uzmanlaşma veya esnek 'birikim rejimi' ile birlikte istihdam yapısının dönüştüğü, sosyal devletin belirli sorumluluklarını üzerinden atmasıyla birlikte zaten istihdam yapısındaki dönüşümden etkilenen kesimlerin daha da marjinalleştiği ve kentlerin kendi kaderlerini belirlemek durumunda kaldığı bir rekabet ortamının oluştuğu şeklinde

\footnotetext{
2 Kavramların farklı şekillerde kullanılmasında 1980'ler ve 1990'lar kentleşme yazınının biçimlenmesinde önemli etkisi olan Marxist kökenli Düzenleme Okulunun da payını vurgulamak gerekir. Okulun önde gelen isimlerinden Jessop'ın yekpare bir kuramsal sistemden ziyade devam etmekte olan bir "araştırma programı" olarak tanımladığı Düzenleme Okulu içerisinde hem Marxizm ile ilişkisi farklı olan, hem de sanayi kapitalizminde yaşanan dönüşümü tanımlarken kullanılan Fordizm ve post-Fordizm kavramlarını farklı şekilde ele alan yaklaşımlar mevcuttu (Jessop, 1990, s. 153-154). Bu durumun esneklik kavramının kullanımı çerçevesindeki yansımasına örnek olarak Lovering'in (1990) esnek üretim olgusu üzerine çalışan Scott'a (1988) yönelik eleştirilerine ve bu tartışmayı da çerçeveye alan Tickell ve Peck'in (1992) Düzenleme Okulu ile kurumsalcı yaklaşımlar arasındaki benzerlik ve farklara dair tespitlerine bakılabilir.
} 
yansıdı. Bu görüş çerçevesinde yürütülen tartışmalar, ekonomik gelişmişlik, küresel ekonomideki konum, devletin ve yerel siyaset sisteminin işleyişi, sınıfsal ve etnik yapı alanlarındaki farklılıklar çerçevesinde yapılan karşılaştırmalar üzerinden yürütüldü. Bunun sonucunda karşılaştırmalı yaklaşımlar dahi belirli eğilimleri tanımlayan 'esneklik', 'rekabetçi kentler', 'dışlanma' ve 'sınıf-altı' gibi kavramlar üzerinden yürütüldü.

Kentleşme literatüründe söz konusu dönemin tartışmalarında belirli kavramların aşırı popüler hale gelmesi ve bağlamsal farklılıklar göz ardı edilerek kullanılması, Wacquant'ın daha sonra üzerinde sıklıkla duracağı bir mesele olacaktır. Ancak konu yalnızca akademik yazında söz konusu olan bir kavram hassasiyetsizliği meselesi değildir. Bourdieu sosyolojinin özerkliğini kazanmakta zorluk çekmesini nedenini bilgi nesnesinin üzerine hakikat üretme yetkisinin yalnızca sosyologlara bırakılamayacak kadar önemli ve tartışmalı olması ile açıklar. Bundan dolayı başta iktidar sahipleri olmak üzere herkes sosyolojinin nesnesi üzerine görüş belirtme ve toplumsal dünyanın tanımlanması mücadelesinde yer alma hakkını kendisinde bulmaktadır (Bourdieu,2001/2004, s. 86-87). Aynı meseleye değinen Bauman ve May sosyolojinin konusu olan olguların halihazırda "sağduyusal bilginin" (comonsense knowledge) nesnesi olduğunu, bu anlamda sosyolojik kavramların "sıradan insanlar" tarafından verilen anlamlarla yüklü olduğunu söyler. Bu durum kendisini sağduyunun ürettiği bilgiden ayırt etmesini sosyolojinin kimliği açısından önemli bir mesele haline getirir. (Bauman ve May, 1990/2001, s. 5-8). Sosyolojinin üzerinde bilgi üretme tekeli kuramadığı bu olguların hem gündelik hayatta, hem de medyada yoğun olarak ele alınmaları da aynı durumun bir yansımasıdır. Wacquant, Bourdieu ile beraber bu konu üzerinde durmuş, gelişmiş ülkelerde son yıllarda yaşanan dönüşümlere yönelik tartışmalarda kamu görevlilerinden medya entelektüellerine birçok çevrede küreselleşme, esneklik, yönetişim, kimlik ve sınıf-altı gibi kavramların yoğun olarak kullanıldığını; buna karşın kapitalizm, sınıf ve sömürü kavramlarının belirgin şekilde kullanılmamasının bu kavramların işaret ettiği olguların geçersiz ve modası geçmiş olduğu algısını yarattığını ifade etmiştir. Yazarlara göre bu sorunu daha da büyüten etken, bu kavramsal tercihlerin yalnızca bu moda kavramların işaret ettiği dönüşümleri destekleyen neoliberal çevrelerce değil, araştırmacılar, yazarlar, sanatçlar ve sol-kanat aktivistler tarafından da yapılmasıdır (Bourdieu ve Wacquant, 2001, s. 2). 
Kentlerin toplumsal çelişkilerin doğrudan doğruya vücut bulduğu mekânlar olması ve kentsel sorunların hem gündelik hayatta sürekli tartışılan, hem de medya gündeminde kolay yer bulan meseleler olması, söz konusu durumun kent sosyolojisi göz önünde bulundurulduğunda daha da belirgin hale gelmesi sonucunu doğurduğunu söylemek mümkündür. Kentsel deneyim bir yandan gündelik yaşamın sunduğu fotoğrafların estetize edilmesi, otantikleştirilmesi ve romantize edilmesine neden olacak pırıltıyı taşıyabilmekte, öte yandan kişilerin aynı mekânı paylaştıkları insanları yabancı, öteki, dişarlıklı olarak kategorize etmesini beraberinde getirecek tehdit algısını tetikleyebilmektedir. Kent sosyolojisi, sosyolojik kavramlarının basında özensiz şekilde kullanılmasını sürekli olarak bir sorun olarak görmüştür. Burada Wacquant'ın bulduğu her fırsatta eleştirdiği sınıf-altı kavramı üzerinde durmak gerekir.

\section{Sinıf-altı Meselesi}

Sınıf-altı kavramı ilk olarak Gunnar Myrdal tarafından 1960'ların başlarında giderek daha fazla vasıf ve eğitim gerektiren istihdam imkânlarının yaygınlaşmasıyla birlikte bu talepleri karşılayamayan kesimlerin karşı karşıya kaldığı yapısal işsizlik sorununu tanımlamak için kullanılmakla birlikte takip eden dönemde aynı yıllarda popülerleşen 'yoksulluk kültürü' kavramının ve bu kavramların basındaki kullanım biçimlerinin de etkisiyle ırkçı tonlara bulanarak Amerika'nın siyah gettolarındaki yoksulluğu siyah nüfusun bir takım kültürel nitelikleri üzerinden açıklamak için kullanılır hale geldi. Bu süreçte kavramın akademik yazında da büyük oranda bu popülerleşen kültürcü anlamıyla, hatta yoksulluk kültürü kavramının ikamesi olarak kullanıldığı gözlemlendi (Aponte, 1990, s. 118; Morris, 1989, s. 123-125; Yılmaz, 2008, s. 127-128). Bu anlamda sinif-alt1 geçmişten bugüne 'berduş' (vagaond), 'hak etmeyen yoksullar', 'tehlikeli sınıflar' gibi, ekonomik üretkenliği olmayan, çoğunlukla alkolizm ve antisosyal davranış biçimleri gibi kalıtsal olduğu varsayılan özellikler taşıdığı iddia edilen gruplara yakıştırılan yeni bir adlandırma haline geldi (Gans, 1994, s. 270; Magnicol, 1987, s. 296-297; Robinson ve Gregson, 1992, s. 38). Öte yandan Myrdal kavramı istihdam yapısındaki değişimle ilişkilendirmiş ve Gans'ın da ifade ettiği gibi ileride endüstri-sonrası toplum olarak tanımlanacak olan duruma dair bir öngörüde bulunmuştur (Gans, 1993, s. 327). Bu anlamda Myrdal'ın kavramı üzerine temellendirdiği dinamikler 
dolayısıyla sınıf-altı kavramı, 1970'ler ve sonrasında marjinalize olan kesimleri tanımlamak için sıklıkla başvurulan bir kavram haline gelmiş, basında ve akademik yazında yoksulluğun dönüşümü ile ilgili tartışmalarda ön plana çıkmıştır.

Genel anlamda sınıf-altı kavramının, istihdam yapısındaki dönüşümle birlikte marjinalize olan ve emek piyasasının dışında kalan bir kesimin kentlerin belli bölgelerinde yoğunlaşması ve söz konusu marjinal konumun kendi kendini üretir hale gelmesi durumunu tanımladığı söylenebilir. Peterson'a göre kavram çekiciliğini bir taraftan kişilerin karakterleri ile toplum ve siyasetin büyük ölçekli güçlerinin kesiştiği noktada yer almasından, öte yandan Marx'ın lümpen-proletarya kavramının işaret ettiği gibi ekonomik ve siyasal güçler tarafından tahakküm altına alınmış olan, ancak üretici bir rolü olmayan bir grubu tanımlamaya imkan vermesinden almaktadır (Peterson, 1991-1992, s. 617-618). Buna ek olarak kavramın özellikle kent sosyolojisinde bu derece ele alınmasının şaşırtıcı olmadığını ifade etmek gerekir. Kavramı davranışsal anlamıla ele alan araştırmacılar açısından belirli "karakter özelliklerinin" nesilden nesle aktarılması süreci mekânsal bir ortaklığı gerekli kılar. Sınıf-altını oluşturan yapısal süreçlere vurgu yapan araştırmacılar ise bu süreçler sonucunda toplumun belli bir kesiminin izolasyonunu kentin belirli kısımlarına sıkışmaları üzerinden ele almaktadır. Bu izolasyonla ayrımcllık arasındaki nedensellik ilişkisi nasıl kurulursa kurulsun, sınıf-altı kavramı tarihi itibarıyla toplumsal katmanlaşma ve yoksulluk literatüründe kullanılan diğer kavramlara göre çok daha doğrudan bir mekânsal referans yüklenmiş, yoksulluk ve mekân ilişkisini vurgulamak isteyen araştırmacılara paradigmatik anlamda olmasa dahi dil anlamında bir ortaklık imkânı sağlamış, ancak Wacquant'ın eleştirilerinden de görüleceği üzere bu ortaklık aynı zamanda kentsel yoksulluğun yapısını anlama girişimine karşı bir epistemolojik engel oluşturmuştur.

Amerika bağlamında, sınıf-altının ekonomik yaşamda marjinalize olmuş bir grubun mekânsal anlamda belirli bir bölgede yoğunlaşması ile açıklanmasından dolayı genel olarak siyah nüfusa özgün bir durum olarak ele alınmıştır. Sınıf-altı yazınında bu durum siyah nüfusu gettonun tarihsel oluşum sürecinde Amerika'ya göç eden diğer gruplarla siyah nüfusun yaşadığı ayrımcılık arasındaki niteliksel farklar ve diğer grupların ekonomik ve siyasal hayatta örgütlenme başarısına karşılık siyahlarda böyle bir sürecin yaşanmaması üzerinden ele alınmıştır. Wacquant sınıfaltı kavramını gelişmiş ülkelerde kentsel yoksulluğun yeni biçimlerine 
dair yürüttügü çalışmalarda sıklıkla eleştirel bir şekilde ele almıştır. Bu noktada sınıf-altı yazınında önemli yeri olan ve Wacquant'ın kendi yaklaşımıyla yer yer karşılaştırdığı (Wacquant, 2008/2010a, s. 14) iki kitap üzerinde kısaca durmak gerekir. Bu çalışmalar Wacquant'ın Chicago Üniversitesi'nde doktora yaparken beraber çalıştı̆̆ 1 Wilson'ın Truly Disadvantaged (1987) kitabı, diğeri ise Massey ve Denton'ın American Apartheid (1993) başlıklı çalışmasıdır.

Wilson 1960'lara kadar gettolarda belirli bir toplumsal örgütlenmenin var olduğunu, bunun bir komünite hissini beraberinde getirdiğini ve buralarda yaşayan kesimlerin kendilerini yaşadıkları mahalle üzerinden kimliklendirdiklerini söyler. Bu komünite hissi belirli davranışsal normlar tanımlamış ve bu sayede yüksek seviyede yaşanan yoksulluğa karşın daha sonraki dönemlerde bu mahallelerde yaygın olduğu kabul edilen sorunlar belli bir derecenin üzerine çıkmamıştır. Ancak 1960'lı yıllara kadar işçi sınıfına mensup siyahlarla beraber kent merkezindeki gettolarda yaşayan siyah orta sınıf, bu tarihlerle birlikte kentlerin diğer kısımlarında veya dışında bulunan konut alanlarına taşınmaya başlamış, toplumsal örgütlenmenin işleyişi açısından önemli olan bu kesimin gidişi sınıf-altının oluşumunda önemli bir etken olmuştur. Wilson aynı dönemlerde Amerika'nın kuzeyindeki büyük kentlerde artan siyah göçü ile birlikte bu kentlerdeki gettolarda genç nüfus oranının hızla artmış olduğunu belirtir. Bu durumun istihdam yapısındaki dönüşümle çakışması ile birlikte geldikleri kentlerdeki yeni iş alanlarında çalışma vasfına sahip olmayan bu genç nüfus sınıf-altının çekirdeğini oluşturmuştur (Wilson, 1987, s. 3, 142-143).

Sınıf-altının oluşumunda belirleyici faktörün ekonomi olduğuna yönelik kabulü Wilson'ı bu kavramı ırkçı tonlar barındıracak şekilde kullanan kültürcü yaklaşımlardan farklılaştırmakla birlikte Wilson kültürel niteliklerin sinıf-altı olgusunu anlamak için önemli olduğunu vurgular. Bu noktada Wilson kendi yaklaşımını, eleştirdiği ırkçı tonlar taşıyan yaklaşımlardan farklılaştırmak için anahtar bir kavram olarak 'yoksulluk kültürü' yerine 'sosyal izolasyon' kavramını ortaya koyar. Wilson yoksulluk kültürü kavramının sınıf-altını oluşturan kesimlerin karakter özelliklerinin yapısal nitelikteki sınırlılıklar ve imkânlar bütününden özerk hale geldiğini ve toplumsal mobilite imkânları artırıldığında dahi ortadan kalkmayacağını ima ettiğini söyler. Buna karşılık sosyal izolasyon kavramı, ırkçı politikalarla başlayıp kent merkezlerinin sınıfsal yapısında ve kentlerdeki ekonomik yaşamda meydana gelen dönüşümlerle birlikte artan bir süreci betim- 
lemektedir. Bu yaklaşım yoksulluğun yoğunlaştığı bölgelerdeki davranışları anlamakta kültürel niteliklerin önemsiz olduğunu savunmamakta, ancak kültürü yapısal sınılılıklara verilen bir tepki olarak görmektedir. Wilson açısından buradaki nedensellik ilişkisini doğru kurmak sosyal politika geliştirebilmek adına önemlidir. Zira yoksulluk kültürü anlayışı çerçevesinde geliştirilecek olan yaklaşımlar söz konusu kültürel nitelikleri dönüştürmeyi hedefleyecekken, soruna sosyal izolasyon perspektifinden yaklaşmak bu niteliklerin ortaya çıkıp kendini yeniden üretir hale gelmesine neden olan yapısal sınırlılıkları ortadan kaldırmaya yönelik olarak geliştirilebilecektir (Wilson, 1987, s. 61, 137, 147).

Massey ve Denton'in getto olgusuna ve sınıf-altının oluşumuna dair görüşleri, Wacquant'ın da ifade ettiği üzere konuya ekonomik süreçleri merkeze alan Wilson' dan farklı olarak ırk ayrımına odaklanarak biçimlenmiştir. Wilson gibi gettonun 1960'lar sonrasındaki dönüşümü üzerine odaklanan Massey ve Denton, dönüşümün yaşanması öncesi ve sonrasına tanıklık eden araştırmalardan hareketle yoksulluk ve baskıya rağmen Amerikan toplumunun temel değerlerine bağlı kalan getto sakinlerinin ideal yaşam şartlarına kavuşma imkânlarından yoksun bırakılmaları sonucu tatmin için başka araçların arayışına girdiklerini ve bunun sonucunda özerk bir "yeni getto kültürü" geliştirdiklerini iddia ederler. İzolasyon ve aşırı yoksulluğun yarattığ1 ve toplumun geri kalanında kullanılandan farklı bir dil üretmiş olan bu "muhalif kültür", gettoda yaşayan insanların eğitime önem vermek gibi toplumda başarılı olmanın yolu olarak görülen faaliyetlere katılmaması yönünde içeriden bir baskı unsuru oluşturmuştur. Bu durum söz konusu yoksulluğun kendisini yeniden ürettiği bir ortamı beraberinde getirmiştir (Massey ve Denton, 1993, s. 162-165, 171173, 184-185).

Yazarlara göre siyah gettosunun sürekliliğinden sorumlu olan temel yapısal faktör ırk ayrımcılı̆̆ıdır ve (Wilson'ın yaklaşımının aksine) ekonomik nedenlerden kaynaklanmamaktadır. Ayrımcilığın seviyesi diğer etnik gruplar için gelir düzeyi arttıkça azalmakla birlikte farklı sınıfsal pozisyonlarındaki siyahların maruz kaldıkları ayrımcılı̆̆ın seviyesini çok farklı değildir. 1960'larda kentsel yoksullukla ilgili bir takım uygulamalar devreye sokulmuş olmakla birlikte gettonun varlığını neden sürdürdüğü sorusunun "basit cevabi" Amerika'nın beyaz nüfusunun aslen gettonun varlığını sürdürmesinden yana olması ve mekânsal ayrımın devam etmesini istemesidir. Banliyölerin oluşumunu desteklerken kent merkezlerin- 
deki yatırımlara kredi desteği sağlamayan, beyaz nüfusun banliyöye kaçışını teşvik eden otoyollara yatırım yaparken bir yandan da siyah nüfusun kent merkezlerinde yoğunlaşıp izole olmasını sağlayacak olan federal düzenlemeler siyah gettoların varlığını sürdürmesini garanti altına almıştır. Emlak piyasasının aktörleri de siyahların beyazların yaşadığı konut alanlarında oturmasını değer kaybı yaşanacağı düşüncesiyle istemeyerek "yoksulluğun yapısal koşullarının" önemli bir ayağını oluştururlar. Diğer etnik gruplardan çok daha fazlasıyla mekânsal olarak belli bölgelerde izole olmalarının siyah nüfusu siyasal alanda başka gruplarla koalisyon kuramayacakları bir konuma yerleştirdiğini ifade eden yazarlara göre siyah politikacılar da bu mekânsal yoğunlaşmadan çıkar sağlamaktadırlar. Hatta bir takım örneklerin ortaya koyduğuna göre oy tabanını kaybetmek kaygisıyla getto nüfusun kente entegrasyonuna engel oluşturmuşlardır (Massey ve Denton, 1993, s. 9-11, 155, 186-187, 212-214).

$\mathrm{Bu}$ ve benzeri çalışmaların tanıklık ettiği ve sinıf-altı kavramı üzerinden ele aldığı yeni kentsel yoksulluğun Amerikanlaşmaya başladığı düşünülen Avrupa kentlerinde de ortaya çıkacağı yönündeki kaygılar 1980'ler ve 1990'larda sıklıkla dile getirilmeye başlanmıştır. Avrupa metropollerinde sınıf-altının oluşumuna dair tartışmalar Amerika örneği ile karşılaştırmalar üzerinden yürütülmüştür. Örneğin Silver'a göre İngiltere'de sınıf-altı kavramı Amerika'daki anlamından ziyade, T. H. Marshall'ın vatandaşlık kavramsallaştırması çerçevesinde katılım olanaklarından dişlanma üzerinden tartışılmış, bu yeni yoksulluğun tanımlanmasında ırk değil işsizlik, işçi sınıfının parçalanması ve vatandaşlık konularına odaklanılmıştır (Silver, 1993, s. 343-344). Bu tarz karşılaştırmalı değerlendirmeler yapılmakla birlikte, Avrupa metropollerinde emek piyasasından uzaklaşmış kesimin daha da marjinalleşerek sınıf-altı nitelikler taşıyan bir nüfusa dönüşebileceğine dair kaygılar da dile getirilmiştir. Avrupa örneğinde Amerika'nın siyah nüfusun rolünü 1960'larla birlikte Avrupa'ya göç eden "misafir işçiler" ve takip eden dönemdeki diğer göçmen gruplar alır. İstihdam yapısındaki dönüşümde ise sanayi-sonrası topluma geçiş olgusunun yanı sıra Avrupa Birliği'nin getirdiği ekonomik entegrasyonun etkisi üzerinde durulmuştur. Amsterdam'daki durumu değerlendiren Musterd ve Ostendorf, banliyölerde konut sahipliği eğiliminin arttığını ve buna karşılık kiralık sosyal konutların büyük oranda kent merkezinde sunulduğunu, bu sürecin sınıf-altının oluşumunda belirleyici unsur olan mekânsal ayrışmanın yolunu açtığını söylerler. Araştırmacılara göre (makalenin yayınlandığı tarih itibarıyla) sosyal devlet Hollanda'da 
sınıf-altının oluşumuna neden olacak derecede bir kutuplaşmayı henüz önleyebilmektedir. Bununla birlikte konut piyasasındaki dinamiklerle birlikte kent merkezinde toplanmakta olan göçmen nüfus, toplumun geri kalanına göre eğitimde geri kaldığından ve Hollanda ekonomisinin bu kesimlerin çalıştığı vasıf gerektirmeyen iş imkânlarını gelecekte sunmama ihtimalinden dolayı kalıcı işsizlik ve sosyal devlet yardımlarına bağımlı bir sınıf-altına dönüşme riski ile karşı karşıyadırlar (Musterd ve Ostendorf, 1994, ss. 250-251). 1990'lar Berlin'ini değerlendiren Haussmann ve Sackmann ise Berlin Duvarı'nın yıkılması sonrasında kentin göçmen nüfusunun istihdam imkânlarının azaldığını ve işsizlik ve sosyal yardım bağımlılığının arttığı bu kesimin sınıf-altına dönüşme ihtimali olduğunu söylerler (Haussmann ve Sackman, 1994: 239). Brüksel'deki sosyo-mekansal kutuplaşmayı değerlendiren Kesteloot ise kentte kelimenin doğru anlamıla bir gettonun varlığından bahsedilemeyeceğini, bununla birlikte bazı mahallelerin \%70-80 oranında göçmenleri barındırdığını ifade eder. Kentin genç nüfusunun çoğunluğunu barındıran bu bölgeler uzun vadede marjinalleşme riski taşımaktadırlar (Kesteloot, 1994, ss. 211-212).

Wacquant Amerikan siyah gettosuna dair kendi yaklaşımının kent sosyolojisi yazınında kabul gören görüşlerden farkını ifade ederken, ekonomik faktörleri öne çıkartan Wilson'ın ve ırk ayrımına odaklanan Massey ve Denton'ın çalışmalarını siyah gettosunda yaşanan dönüşümde devlet politikalarının rolünü göz ardı ettikleri için eleştirir. Wilson kamu politikalarını yalnızca "onarıcı" işlevleri çerçevesinde ele almakta, gettoda yaşanan dönüşümü "kör piyasa mekanizmasının" bir sonucu olarak görüp devletin bu süreçteki payını ıskalamaktadır. Massey ve Denton'ın ırk ayrımcllığ1 vurgusu ise, söz konusu ayrımcılık aslen gettoyu oluşturduğundan bu yana varlığını sürdürmekte olduğu için, gettodaki dönüşüm ile ırkçıllğın devletin uygulamalarındaki işleyiş biçimindeki dönüşümler arasındaki ilişkileri görememektedir (Wacquant, 2008/2010a, s. 107-108). Amerikan sosyoloji yazınını bu şekilde eleştiren Wacquant, bunun yanında söz konusu tartışmalarda ön plana çıkan sınıf-altı kavramının Avrupa'da yaşanan dönüşümü açıklamak için kullanılmasına da karşıdır. Eleştirdiği bu değerlendirmelerin yerine, bağlamsal farkların kurumsal süreçlerin işlemesindeki etkisini açılayabilen ve devletin kentsel yoksulluğun dönüşümündeki rolünü ön plana çıkartan yeni bir kavram seti önerir. 


\section{İleri Marjinallik, Hipergetto ve Cezai Devlet}

Wacquant'ın kent olgusuna dair yürüttüğü tartışmaların iki boyutu olduğu söylenebilir. Birinci boyut 1970'ler sonrası kentleşme süreçlerinde Amerika ve Avrupa'da yaşanan süreçlere dair görüşlerin bağlamsal farkları göz ardı eden tutumlarını eleştiren karşılaştırmalı yaklaşımdır. Wacquant'a göre Avrupa metropollerinde yeni ortaya çıkan yoksulluk formlarının etnik-ırksal ayrımcılıkla örtüşmesi kentleşme yazınında "Atlantik-ötesi yakınsama tezi" olarak tanımladığı bir yaklaşımın ortaya çımasına neden olmuştur. Kavramların bu Atlantik-ötesi yayılımı, ikili kent, getto ve sınıf-altı gibi kavramların Avrupa metropollerini betimlemek için kullanılması sonucunu beraberinde getirmiştir. Wacquant bu kavramların işaret ettiği olguların Avrupa'daki kentsel yoksulluğu betimlemekte kullanılmasını eleştirmekle beraber, 1960'lar sonrası dönemde gelişmiş ülkelerde ortaya çıan ve "ileri marjinallik" olarak tanımladığ 1 bir durumun ortaya çıktığını savunur. Diğer bir deyişle, Avrupa'da gettolaşma ve sınıfaltı oluşumunu eleştirmek, Atlantik'in iki yakasında ortaya çıan ve belli ortaklıklar taşıyan yeni bir kentsel yoksulluk halinden bahsetmeye engel değildir (Wacquant, 1993, s. 366-367; Wacquant, 2002a, s. 221-222; Wacquant, 2008/2010a, s. 16-17; Wacquant, 2007, s. 66-67). Wacquant Amerika ve Avrupa kentleri arasındaki farklara dair karşılaştırmalı değerlendirmelerini ve ileri marjinallik başlığı altında tespit ettiği ortaklıkları Amerikan siyah gettosu ile Fransız banliyösüne dair çalışmaları üzerinden ortaya koymuştur.

Kuzey-doğu ve orta-batı Amerika'nın metropollerinde oluşan ve Wacquant'ın "kara kuşak" olarak tanımladığı gettolar ile başta Paris olmak üzere Fransız kentlerinin diş çeperlerindeki eski işçi sınıfı yerleşim alanları olan ve Wacquant'ın "kızıl kuşak" olarak tanımladığı banliyöler arasındaki en belirgin fark siyah kuşakta ayrımın renk üzerinden ortaya çıkıp sınıfsal fark ve devlet uygulamaları ile güçlendirilmesine karşılık, kızıl kuşağın oluşumunda temel belirleyenin sınıfsal farklılık olması ve devletin çeşitli uygulamalarıyla bu durumu hafifletmeye çalışmasıdır. Bunun sonucu olarak Amerikan gettosu irksal ve kültürel olarak homojen bir yapıya sahip ve devletin sinırlı müdahalede bulunduğu alanlarken, Fransız banliyösü sınıf ve etnisite anlamında heterojen bir yapıya sahiptir ve kamu kurumlarının varlığı kendisini hissettirmektedir. Banliyölerin get- 
tolaştığı tezinin yanlışlığının da ötesinde, Wacquant heterojen etnik yapısı, geçirgen sinırları ve ortak bir kültürel kimlik yaratma anlamındaki kapasitesizliğini vurgulayıp gettolardan ne derece farklı olduklarını ortaya koymak için banliyöleri "anti-getto" olarak tanımlar (Wacquant, 1993, s. 368; Wacquant, 2008, s. 115).

Wacquant bu noktada iki devletin konuya yaklaşımı arasındaki farkı vurgular. Buna göre Amerikan gettosuna yönelik kamusal programlar 1990'lara doğru neredeyse tamamen ortadan kalkmaktayken, Fransa'da aynı tarihlerde devreye giren sosyal yardım ve eğitime yönelik diğer kamusal destek projelerine paralel olarak eski iş̧̧i sınıfı banliyölerindeki sağlıksız yaşam koşullarını ortadan kaldırmaya yönelik programlar devreye sokulmuştur. Wacqaunt bu anlamda devletin yaklaşım biçimi anlamında kendi kaderine terk edilen Amerikan gettosuyla devletin yoğun olarak müdahale ettiği Fransız banliyösü arasında "keskin bir zıtlık" olduğunu söyler. Wacquant'a göre toplumun bir kesiminin belirli bir mekâna sürgün edilmesi ve bu durumun kurumsallaşması Fransa'nın "üniter vatandaşlık ve ulusal topluluğa katılım" ideolojisine aykırı bir durumdur ve bu ideolojinin etkisi, Kuzey Afrika'dan gelen göçmenlerin özerk bir topluluk oluşturmak yerine Fransız kültürel ve davranışsal kalıplarını benimsemiş olmalarından anlaşılabilir. Amerika'da ise en belirgin kurumsal ifadesi olan siyah gettosunun kentlerin verili bir unsur haline gelmesinden de görülebileceği gibi renk ayrımı düzenin parçalarından birisi haline gelmiştir. Amerikan metropollerinde gettoların varlığı o derece kökleşmiştir ki kentlerin ekonomik, siyasal ve toplumsal yaşamının değişmez bir unsuru haline gelmiştir (Wacquant, 1993, s. 373, 378-379; Wacquant, 2008/2010a, s. 180-182).

Bunun yanında, getto ve banliyö sakinlerinin taşıdıkları 'damganın' niteliksel farklılığı, bu iki örnek arasında deneyimsel anlamda önemli bir fark yaratmaktadır. Fransız banliyösünden gelenler, belirli bir fiziksel veya kültürel işaretleyiciyle değil, yaşadıkları yer üzerinden damgalanmışlardır ve nereden geldiklerini saklamaya yönelik stratejiler kullanarak toplumun geneline dahil olabildikleri "birkaç saatlik bir fantezi" yaşama imkanına sahiptirler. Amerikan gettosu sakinleri ise deri renkleri üzerinden damgalanmış oldukları için böyle bir imkâna sahip değildirler. Bunun sonucunda, gettoda yaşayanların tek yapabileceği şey, kızıl kuşakta yaşayanların asla kabul etmeyecekleri şekilde kendilerine vurulan damgayı kabul edip zorunlu olan bu durumu bir zevk haline getirmektir (Wacquant, 1993, s. 373-374). Bu farklar üzerinden değerlendirildiğinde Fransa'da 
veya diğer gelişmiş ülkelerdeki metropollerde dönüşen kentsel yoksulluğun mekânsal niteliğini getto kavramı üzerinden ele almak bir epistemolojik engel teşkil etmektedir.

Bu farklılıklarla birlikte, Wacquant'a göre gelişmiş ülke metropollerinde yaşanan yoksulluğun dönüşümünde belirli ortak noktalar vardır. Kendisinin ifadesiyle, "Atlantik'in iki tarafında renk, sinıf ve yerin (place) birbirlerine farklı şekilde "dikilmiş" olmaları", Amerikan gettosu, Fransız banliyösü, veya İngiltere ve Hollanda'daki kent merkezlerinde, henüz tam oluşmamış olmakla birlikte bazı belirgin nitelikler taşıyan ve hem Amerika'nın geleneksel gettosundan, hem de Avrupa'daki işçi sınıfı yerleşim bölgelerinden farklı olan yeni bir "kentsel marjinallik rejiminin" ortaya çıkmadığı anlamına gelmez (Wacquant, 2002a, s. 222). İleri marjinalliğin ortaya çımasındaki etmenlerden birincisi Fordist kapitalizmin dönüşümü ile birlikte ortaya çıkan yeni istihdam yapısının işçi sınıfı üzerindeki yıpratıcı etkisidir. Güvencesiz, yarı-zamanlı, düşük ücretli işlerin arttığı bu ortamda emek piyasasının çeperinde veya tamamen dişında kalmanın yanı sıra ileri marjinalliği tanımlayan ikinci unsur mekânsal anlamda belirgin sınırları olan izole yerleşim alanlarında yaşamaktır. İleri marjinallği deneyimlemekte olan kesimler yoksulluğun damgalayıcı niteliğinin yanı sıra, yaşamak durumunda kaldıkları mahallelerden dolayı damgalanırlar. Wacquant Fransız banliyölerinde ve Amerikan gettolarında yürüttüğü saha çalışmalarından hareketle bu bölge sakinlerinin yaşadıkları yerden utandıklarını veya kendilerini aslen bu mahallelere ait olmayan kişiler olarak tanımlamaya çalıştıklarını söyler. Damgalanmanın bu etkisi ileri marjinallik deneyiminin bir başka boyutunu, 'yer' (place) hissinin ortadan kalktığı, Wacquant'ın 'bölgesel yabancılaşma' (territorial alienation) olarak tanımladığ 1 durumu berberinde getirir. Bölgesel yabanc1laşma ile birlikte bu bölgeler anlam ve duygu ortaklığının yaşandığı mahalli (communal) 'yerler' olmaktan çıkıp kişilerin hayatta kalmaya çalıştığ ve birbirlerine kayıtsız olarak yaşadıkları 'mekânlara' (space) dönüşür. Mahalli ilişkilerin ortadan kalkması eski işçi mahallelerinde işten çıarılma gibi zorluklar yaşayan kişileri tekrar ayağa kalkana kadar koruma altında tutan informel destek mekanizmalarının da ortadan kalkması anlamına gelmektedir. İleri marjinalliğin Wacquant'ın ifade ettiği son tanımlayıcı niteliği, bu süreçleri deneyimleyen kesimlerin ortak bir dile, "kolektif anlamda kaderlerini tanımlayabilecekleri ortak temsil ve göstergelere" sahip olmamalarıdır. Bunun sonucunda yeni kent yoksulları hem toplumsal, hem de sembolik düzeyde parçalanmakta, bu yeni yapı karşısında 
sendika gibi geleneksel destekleyici kurumlar faydalı olamamaktadır (Wacquant, 2002a, s. 224-228).

$A B D$ ve Avrupa'da kentsel yoksulluğun farklılaştığı ve ortaklaştığı alanlar üzerine dair bu tartışmalar, Wacquant'ın kent sosyolojisi yazınına katkısının birinci boyutunu oluşturur. Bununla birlikte Wacquant'ın kent sosyolojisi yazınına olan temel katkısının Amerikan gettosuna dair yürüttüğü çalışmalar ve tartışmalar olduğunu belirtmek gerekir. Wacquant'ın birçok çalışmasında Amerikan gettosuyla Fransız banliyösü arasında bir karşılaştırma sunduğu doğru olmakla birlikte bu çalışmaların odağında Amerikan gettosu vardır ve söz konusu karşılaştırma, 'Atlantik-ötesi yakınsama tezini' reddetmek amacıyla yapılmıştır. Ayrıca Wacquant ileri marjinalliğin denetim ve cezalandırma sistemindeki dönüşümle ilişkisini ABD örneğinde ayrıntılandırmıştır.

Wacquant siyah gettosunun Wilson'ın ve diğer pek çok getto araştırmacısının vurguladığına benzer bir dönüşüm geçirdiğini ifade eder. Buna göre, siyahlara karşı yürütülen ayrımcılık süreciyle oluşmuş olan gettolar özellikle siyah orta sınıfın oluşmaya başlamasıyla beraber "birliktelik bilinciyle birbirine bağlanmış siyah sınıfların hepsini" barındıran komünal bir yapı kazanmıştı ve tüm getto sakinlerine mobilite ve temsil imkânları sağlayacak şekilde işlev görmekteydi. Bazı kentlerde orta sınıf siyahlar gettodan uzaklaşıp daha cazibeli konut bölgelerinde yaşamayı tercih etmekle birlikte sınıfsal mesafe bu kesimi aile ve toplumsal bağlarla bağlı olduğu gettodan uzaklaştırmamıştı. Ayrımcılığa uğrama anlamında getto sakinleriyle aynı kaderi paylaşan orta sınıfların ekonomik gücü büyük oranda getto komünitesine sağladıkları mal ve hizmetlerle oluşuyordu ve "1rkın gelişmesi" yönündeki kaygılarla bir araya gelerek, İkinci Dünya Savaşı sonrası Fordist dönem gettosuna toplumsal ve yapısal anlamda entegre bir kimlik kazandırıyordu. Ancak örgütlü bir yapısı olan, bir "toplu dayanışma ve seferberlik aracı" olarak işleyen komünal getto 1970'lerle birlikte dönüşmeye başlamış, "tampon işlevi" gören örgütsel yapının ortadan kalkmasıyla birlikte komünal getto Wacquant'ın "hipergetto" dediği, ileri marjinalleşmenin yaşandığı mekânlara dönüşmüştür (Wacquant, 2001, s. 103-104, 107; Wacquant, 2008/2010a, s. 60, 76). Bu dönüşüm Fordist yapının ortadan kalkmasıyla birlikte ortaya çıan yeni yapı ve refah devleti uygulamalarındaki kısıtlamalardan kaynaklanmış, toplu konut projelerinin kentlerin en yoksul mahallelerinde gerçekleştirilmesi gibi uygulamalarla devam ettirilen, siyah nüfusu belli yaşam alanlarına sürme politikasının varlığını sürdürmesiyle söz konusu dönüşümün etkisi daha 
da ağırlaşmıştır. Wacquant komünal gettonun hipergettoya dönüşümünü makroekonomik dönüşümler üzerinden açıklamanın yanlışlığının, asıl belirleyici faktörün gettoda yaşayanları bu süreçlerin insafına bırakma kararı veren kent seçkinlerinin iradesi olduğunun altını çizer (Wacquant, 2008/2010a, s. 84-85).

Wacquant'a göre hipergettonun teşkilindeki temel gerilim, Bourdieu'nun "devletin sol eli" olarak tanımladığı, devletin sosyal yardım ve destek programların ifade eden kısmı ile Bourdieu'nun "devletin sağ eli" olarak tanımladığı, finansal kaygılar doğrultusunda hareket eden ve sol elin talep ettiği kalemlere bütçe ayırmamak için sürekli direnen, kısım arasındaki çatışmaya dayanır (Bourdieu, 1998, s. 1-2; Wacquant, 2009, s. 6). Gettodan hipergettoya geçiş sürecinde devletin kentsel yoksullukla ilgili programlarını kısmasını ise Smith'in kentleşme yazınına uyarladığı rövanşizm kavramı üzerinden tanımlar (Wacquant, 2009, s. 57). Smith rövanşist kent tanımın 1990'larda New York'taki "suç, şiddet, uyuşturucu, kullanımı, işsizlik, göçmenler ve ahlak-düşüklüğü" gibi olguların yaygınlığ yönünde yoğun kaygıların medya ve siyaset kanalıyla yaygınlaştırıldığı, "1rk/sınıf/toplumsal cinsiyet" üzerinden yürütülen terör kampanyası sonucunda orta ve üst sınıf beyazlar arasında yaratıldığını iddia ettiği bir tavra dayandırır. Kavrama kaynaklık eden on dokuzuncu yüzyıl Fransa'sındaki harekette olduğu gibi, kaybettiklerini düşündükleri şeyleri geri almak isteyen bu sınıflar yaratılan bu algı ile birlikte evsizler, işsizler, kadınlar, göçmenler, gey ve lezbiyenler gibi kesimleri New York'taki yaşam tarzını tehdit eden unsurlar olarak görmeye başlamış ve kenti bu kesimlerden "geri almaya" yönelik uygulamaları desteklemişlerdir (Smith, 1996, s. 210-232).

Ancak bu rövanşist tavır, iki yönlü ilerlemektedir. İstatistiki veriler bunu göstermese de toplumun genelinde sosyal yardımlardan büyük oranda gettoda yaşayanların faydalandığı, bu yardımların onları tembelliğe ve ahlak-dışı yaşam biçimlerini sürdürmeye teşvik ettiği yönünde bir alg1 oluşmuştur ve 1960'lardan 1990'lara gelen süreçte medyada yer alan yoksulluk hikâyelerinde siyahların giderek daha ağırlıklı olarak temsil edilmesi de bunda etkili olmuştur (Wacquant, 2009, s. 82-83). Devlet yoksulluğun kriminalize edilmesi üzerinden yürüyen bu sürece paralel olarak getto üzerindeki denetim mekanizmalarını da artırmıştır. Wacquant, Bourdieu'nun devletin sağ eli olarak tanımladığı kısma polis, mahkemeler ve hapishane kurumunu ekleyerek Keynesyen dönem sonrası devletin sol 
elinin geri çekilmesiyle birlikte derinleşen eşitsizlik ve yoksulluğun karşısinda devreye sokulan cezai uygulamaları analizin merkezine kaydırmayı hedefler. Wacquant'a göre yoksullara yönelik yardımlarla ceza ve kapatma sistemlerinin feodalizmden kapitalizme geçiş sürecindeki ortak tarihsel kökeni daha sonra unutulmuş, toplumsal refaha yönelik uygulamalarla cezalandırma olgusu farklı çalışma alanları haline gelmiştir. Ancak neoliberalizmin sosyo-ekonomik etkileri bu olguların birbirleriyle tekrar bağlantılı olarak işlemesi sonucunu beraberinde getirmiştir. Bundan dolayı günümüzde devleti ve toplumsal katmanlaşmayı anlayabilmesi için sosyolojinin refah devleti olgusu ve uygulamalarıla birlikte mevcut durumda kriminolojinin çalışma konusu olarak ayrı bir yere konulmuş olan cezalandırma olgusu üzerine çalışmalı ve bunlar arasındaki ilişkiyi görebilmesi gerekir (Wacquant, 2009, s. 16, 289, 291).

1970'lerle birlikte ABD' de devletin diğer ülkelerin ceza ve kapatma sistemleriyle karşılaştırıldığında çok daha "cezalandırıcı" (punitive) bir nitelik kazandığını iddia eden Wacquant'a göre bunun nedeni suç eylemlerinin yapısında veya niceliğinde değil, kamu otoritesinin ve oy tabanının çoğunluğunu oluşturan beyaz orta sınıfın yaklaşımındaki değişimdir. Wacquant'ın hiper-kapatma (hyperincarceration) olarak adlandırdığı bu yoğunlaşan cezalandırma ve kapatma sürecinden ekonomik anlamda zaten istikrarsızlaşmış olan sınıflar daha fazla etkilemiş, komünal gettonun çöküşü sonrasında getto sakini siyah nüfus, polis ve yargı sisteminin s1nıfsal ve ırksal önyargılarının de etkisiyle, bu süreçte birincil hedef haline gelmiştir. Hapishanelerin sayısındaki artış, mahkûmiyet sürelerinin uzaması ve cezaların sertleşmesinin yanı sıra denetimli serbestlik ve şartlı tahliye mekanizmaları hapishanedeki mahkumlardan çok daha geniş bir nüfusun denetim altına alınmasına imkân tanımıştır. Wacquant şartlı tahliyenin işleyişine dair düzenlemelerdeki değişimlerle birlikte bu sistemin hapishaneye alternatif olmaktan ziyade onun bir uzantısı haline geldiğini ve bir tür "cezai tuzak" (penal trap) şeklinde işlev gördüğünü savunur. Sosyal devletin işlemediği hipergettoda ıslah sistemi alt sınıf vasıfsız genç siyah erkeklerin devletle tek temas noktasını oluşturmaktadır ve istatistiki veriler bu gruba dahil siyah nüfusun büyük oranda hapishane, denetimli serbestlik veya şartlı tahliye altında bu yapıya tabi olarak yaşadıklarını göstermektedir. Bu noktada hapishane kurumu ABD' de yoksulluk "yönetiminin" asal kurumlarından biri haline gelmiştir (Wacquant, 2009, s. 63, 125-129; Wacquant, 2010b, s. 76). 


\section{Amerikan Kent Sosyolojisinin Eleştirisi}

Wacquant Amerikan siyah gettosu üzerine araştırmalar yürütmeye Wilson'ın başında olduğu bir projede görev alarak başlamış ancak daha sonra Wilson'a ve genel olarak Amerikan sosyolojisine karşı eleştirel bir tutum takınmıştır. Wacquant'ın Amerikan kent sosyolojisine yönelik eleştirileri üç başlık altında toplanır. Bunlardan birincisi getto kavramının "sulandırılması" ve bu bölgelerin oluşumunun ve sonrasında hipergettoya dönüşümünün altında devletin rolünün göz ardı edilip basitçe yoksulluğun yoğunlaştığı bölgeleri tanımlamak için kullanılması, bu anlamda kavramın tarihsel anlamının ve sosyolojik içeriğinin boşaltılmasıdır (Wacquant, 1997, s. 341). Wacquant'm bu eleştirisi Amerikan kent sosyolojisi geleneğine dair uzun zamandır dile getirilen eleştirilerin bir uzantısı olarak görülebilir. Castells 1970'lerde bu geleneğin yapı taşlarını oluşturan Chicago 'kentsel ekoloji' okulunu değerlendirirken, bu okulun şehir olgusunu anahtar kavramları olan 'boyut', 'yoğunluk' ve 'heterojenlik' anlamında gerekli şartların oluşması durumunda ortaya çıkan kültürel bir olgu olarak tanımlama eğiliminin söz konusu şartların oluşumunda asıl belirleyici etken olan endüstriyel kapitalizmle örtüşen toplumsal örgütlenme tarzını göz ardı ettiğini ifade etmiştir (Castells, 1972/1977, s. 77-81). Bu ve benzeri eleştirilerin Wacquant'ın görüşleriyle ilişkisi, kapitalizmin veya Castells'in üzerinde durduğu devletin 'göreli özerkliğinin' kentleşmeyi biçimlendirmesindeki etkisinin göz ardı edilmesinden ziyade, kentin oluşum ve dönüşümünü doğal süreçler olarak görüp bunun altında yatan ekonomik ve siyasal etkenlerin göz ardı edilmesi durumudur. Amerikan kent sosyolojisinde önemli yeri olan ve Marksist ve Weberyan kentleşme kuramlarının yoğun eleştirilerine (Harloe, 1978, s.1-10) rağmen etkisi devam eden ekolojik yaklaşım (Flanagan, 1993, s.66-68), bu anlamda siyahların kültürel özelliklerini gettoların sorunlu bölgeler olmasında etkili olduğunu ima eden değerlendirmelerle, bunlara doğrudan kaynaklık etmese de, uyum içerisindedir. Wacquant gettonun doğal süreçlerin sonucu olarak yoksulların yoğunlaştığı mekânlar olarak değil, "etno-ırksal kapatma ve denetim mekanizmalarının" oluşturduğu kurumsal bir olgu olarak tanımlanması gerektiğini savunur. Gettoyu yoksulluğun yoğunlaşmasının bir sonucu olarak görmek bu iki olgu arasındaki nedensellik ilişkisini tersine çevirmek anlamına gelmekte ve Amerika'da neden özellikle siyah nüfusun yoğun olarak gettolarda yaşamakta olduğu sorusu başta 
olmak üzere gettonun gerçekliğini görmemizi sağlayacak olan soruların sorulmasinı engellemektedir (Wacquant, 1997, s. 343; Wacquant, 2008/2010a, s. 63).

Wacquant'ın Amerikan kent sosyolojisine yönelik ikinci eleştirisinin merkezinde Chicago okulunun kentleşme yazınına yerleştirdiği "örgütlenme" (organization) kavramı yer almaktadır. Toplumsal örgütlenme kavramı kenti grupların kendi yerleşim alanlarını oluşturmak için rekabet ettikleri bir serbest piyasa alanı olarak ele alan ve adaptasyon ve doğal gelişim olgusunu merkeze alan insan ekolojisi anlayışının bir uzantısıdır. Buna göre örgütlenmenin beraberinde getirdiği denge durumu kente yeni gelen grupların kenttekilerin yaşadıkları bölgelere yerleşme çabasıyla birlikte bozulup hem mahalle, hem de kent ölçeğinde bir "örgütsüzlük" (disorganization) durumunu beraberinde getirmekte, süreç içerisinde bu durum yeniden örgütlenme ile birlikte son bulmaktadır (Hunter, 2014, s. 189190). Örgütsüzlük vurgusu, Durkheim sosyolojisinin kolektif bilincin hızlı toplumsal değişimlere adapte olamamasıyla birlikte ortaya çıktığını savunduğu anomi durumunun bir varyasyonudur. Okulun önde gelen temsilcilerinden Burgess, bu tarz değişimlerin "davranışlar üzerindeki kültürel denetimleri" ortadan kaldırdığını ve bu durumun "ahlaksızlık ve suç", yani "toplumsal örgütsüzlükle" sonuçlandığını iddia ederken, göçmen ailelerin çocukları arasındaki yüksek çocuk suçluluğu oranlarını buna örnek olarak verir (Burgess, 1925/1967, s.150). Wacquant Chicago Okulu'nun gettoyu örgütsüzlük olarak gören anlayışının, yoksulluk ve ayrımcllığı biyolojik anlamda bir büyüme sürecinin sonucu olarak gören ve getto sorununa asimilasyoncu açıdan ele alan bir yaklaşımı beraberinde getirdiğini savunur. Wacquant ahlaki kabullerle yüklü olan örgütsüzlük kavramı ve bu kavramın beraberinde getirdiği gettoyu "düzensizlik ve eksiklik" üzerinden tanımlama alışkanlığına alternatif olarak, karşı karşıya kaldığı "yapısal ve stratejik sinırlamalara" tepki olarak toplumun geri kalanından farklı bir şekilde örgütlenmiş bir getto kavramsallaştırması önerir (Wacquant, 1997, s. 345-346; Wacquant, 2008/2010a, s. 65).

Wacquant Bourdieu'nün bilgi nesnesinin kuramsal olarak inşa edilmesiyle doğrudan bir bağlantısı olmasından dolayı veri toplama sürecinin ast konumunda çalışanlara, araştırma bürokrasilerine (survey bureaucracies) veya asistanlara bırakılabilecek teknik görevlere indirgenemeyeceğini savunduğunu söyler (Wacquant, 1992, s. 29). Başka bir yerde bu durumu "veri toplama" terimi yerine "veri üretimi" (fabrication) terimini tercih ettiğini söyleyerek vurgular. Zira veri toplanabilir değil, "ampirik bir tasarım çerçevesinde 
titiz sorular sorularak" üretilmesi gereken bir şeydir (Wacquant ve Akçaoğlu, 2017, s. 59). Gettonun örgütsüzlük kavramının izinden ele alınmasının da belli ölçüde araştırmaların belirli bir "mesafeden" yapılmasından ve marjinal kesimlerin yaşamını incelemeye uygun olmayan "araştırma bürokrasilerinden" faydalanılmasından kaynaklandığını söyleyen Wacquant (Wacquant, 1997, s. 346), araştırma nesnesiyle bu anlamda mesafesini kısaltan kentsel etnografya çalışmalarını da eleştirmekten geri kalmaz. Wacquant'ın Amerikan kent sosyolojisine yönelik üçüncü eleştirisi özellikle etnografik çalışmalarda ortaya çlkan "gettoyu egzotikleştirme" eğilimidir. Getto sakinlerinin "yaşam dünyasını" anlamanın ve "yerli bakış açısının" yakalayabilmenin sosyolojik araştırmanın ön şartı olmasına karşın, bu yöndeki çabalar getto toplumunu yüceltme riskini de taşımaktadır (Wacquant, 2008/2010a, s. 62). Amerika'da kentsel yoksulluğa dair Duneier (1999), Anderson (1999) ve Newman'in (1999) etnografik çalışmaları için yaptığı değerlendirmelerde Wacquant, yazarların bulgularını saptırmayı göze alarak Amerika'nın kentsel yoksullarında görmek istedikleri "dürüstlük, ahlaklılık ve tutumluluk" niteliklerini ön plana çıkarmaya odaklandıklarını iddia eder. Wacquant'a göre, getto sakinlerini orta sınıf değerlerine istinaden kahramanlaştırıp erdemli kişiler olarak resmetmek, Amerikan siyah gettosuna dair ırkçı tonlar içeren değerlendirmelerde yer alan tek boyutlu, yapay insan tasvirlerini yerinden çıartıp bunun yerine başka yapay tasvirler yerleştirmekten başka bir şey değildir (Wacquant, 2002b, s. 1469, 1520). Wacquant'a göre, bu durum yalnızca söz konusu yazarların kişisel eğilimlerinden veya etnografik çalışmaların barındırdığı risklerden kendilerini kurtaramamalarından ziyade, hem ticari, hem de giderek ticari nitelik kazanan üniversite yayınevlerinin politikalarından kaynaklanmaktadır. Buna göre kamuoyunun dikkatini çeken siyahlar, şiddet ve yoksulluk konularındaki çalışmalar yayınevlerinin politikaları doğrultusunda "apolitik ahlaki masallar" olarak biçimlendirilmekte ve belirli beklentileri karşılayacak şekilde yazılmaktadır (Wacquant, 2002, s. 1524, 1527).

\section{Sonuç}

Sosyal bilimcilerin siyasal angajmanlarının "bilimsel" faaliyetlerine etkisi yaygın bir tartışma konusudur ve sosyoloji bilgi üreticisinin sıklıkla nesnesinin içerisinden konuşmak durumunda olması itibarıyla söz konusu tartışmanın merkezinde olan bir disiplindir. Wacquant'ın çalışmalarının ekse- 
nini oluşturan kentsel yoksulluk ve ayrımcllık gibi konular, işlenmemiş biçimiyle bilgi nesnesi anlamında genel olarak arayıp bulmayı gerektiren bir takım başka araştırma alanlarından farklı olarak her daim görünür olgular olarak bilgi üreticisinin karşısına çıkar. Kentleşmenin işleyişini her nasıl açıklarsak açıklayalım (ekolojik, ekonomik, siyasal), eşitsizlik mekana mıhlanmış şekilde işler ve araştırmacı içinden de geçse, kenarından da dolansa olgunun varlığını yok sayamaz. Bu her an karşı karşıya olma hali, hangi açıdan bakılırsa bakılsın bu olgulara "çözülmesi gereken sorun" niteliği kazandırır. Araştırmacının bu aciliyet karşısında tekerleği yeniden icat etmekten ziyade bu sorunlara dair mevcut tespitlere bakması şaşırtıcı olmamakla birlikte bu durum hazır reçete arayışına dönüşme riski taşır. Dahası, kamuoyunda ilgi gören, sivil toplumun çeşitli yollarla çözüm arayışında olduğu ve bütün bunların yanında devlet bürokrasisinin de olgu tespiti, denetim ve kontrol amaçlı olarak üzerinde çalıştığı bu konular, sosyolojik bilgi üretiminin tahrip olmasına son derece açıtır. Yani bir yandan başka bağlamlardan kuram ve kavramların ithal edilmesi, öte yandan bunların eleştirel bir değerlendirmeden geçmeden dolaşıma sokulması söz konusudur. Bu anlamda "kentsel araştırmalardan elde edilen teorik sonuçların bağlamlarından koparılarak genelleştirilmesi eğilimi" (Arlı ve Göker, 2014, s.129) karşısındaki eleştirel tutumu, Wacquant'ın önemli katkılarından birisi olarak karşımıza çıar.

Acil çözüm gerektirdiği düşünülen sorunlara teşhis koymak için bir takım kavramların üzerinde çok düşünülmeden kullanılması karşısındaki bu tavır, kavramların altında yatan gizil niyetler karşısında tetikte olmak anlamına gelmektedir. Wacquant'in Amerikan sosyolojisinde gettonun temel özellikleri tasvir edilirken kullanılan örgütsüzlük kavramına olan eleştirisi yalnızca yoksul insanların da kendi hayatlarını düzene sokabilecek düzenlemeler yapabileceği yönündeki bir 'taraf tutma' haline işaret etmez. Örgütsüzlük kavramı Amerikan sosyolojisinin apolitik karakteri çerçevesinde analitik bir kavram olarak kullanılmakla birlikte gettoda yaşayanların kendi örgütlenme tarzının toplumun geri kalanıyla uyumlu olması gerektiği kabulüne dayanır ve bu yönüyle bariz siyasal içerimlere sahiptir. Bu anlamda Wacquant'ın bilimsellik iddiasiyla siyasal niteliğinden sıyrılma riski taşıyan yoksulluk konusundaki kavramsal kalibrasyon girişimi aslen sosyal bilimsel araştırmanın olmazsa olmazı olarak görülmelidir. Bununla birlikte bu girişime dair iki sorunun üzerinde durmak gerekir. 
Wacquant'ın yoksulluğun ele alınma biçimine dair uyarıları, araştırmacıyla nesnesi arasındaki mesafeye işaret eder. Bununla birlikte Amerikan gettosuna dair "yerli bakış açısından" bakmaya çalışan yaklaşımların gettoyu egzotikleştirme ve getto sakinlerini yüceltme riskini taşıdığını söyledikten sonra sınıf-altı kavramı ile "soul" kavramı arasında yaptığ karşılaştırma, Amerikan kentsel etnografya çalı̧̧malarına dair ifade ettikleriyle çelişir gibi görünmektedir. "Getto sakinlerinin kendi toplu ve bireysel kimliklerini üretme vasitalarından gittikçe mahrum edildiğini" söyleyen Wacquant (kullanıcılarının niyetlerinden bağımsız olarak) gettoyu denetim altına alma ve disipline etme işlevine sahip olan damgalayıcı sınıf-altı kavramının aksine, siyah nüfusun kendisini kimliklendirmek için kullanıma soktukları "soul" kavramının olumlu bir anlam taşıd1ğını savunur (Wacquant, 2008/2010a, s. 62-63). İşin aslı bu tarz bir karş1laştırma her zaman için kavramın oluşumuna neden olan/imkân veren çerçevenin boyutları üzerinden farklı şekilde yapılabilir. Bu örnekte "soul" kavramının ortaya çıktığı bağlam, Wacquant'ın başka bir yerde de ifade ettiği gibi "yaşam dünyası" açısından Amerikan kültürünün genelinden ayrılmakla birlikte "sistemik" anlamda bir kopukluk söz konusu değildir (Wacquant, 2008/2010a, s. 60). Bunun yanında, Hall'ın da ifade ettiği üzere, toplumda yaşayan grupların kendilerini ifade etmek için kullandıkları kavramların anlamları ideolojik mücadelenin bir konusudur ve belli bir gösterilene sabitlenemezler (Hall, 1985, s. 112). Bu durum Wacquant'in gereğinden fazla üzerinde durduğu ve bulduğu her fırsatta eleştirdiği sınıf-altı kavramı için de geçerlidir. Bu noktada Wilson'ın kavramı ele alış biçimine dönülebilir. Wilson kavrama yöneltilen çeşitli eleştirileri değerlendirirken liberal araştırmacıların sınıf-altı kavramının birbirinden farklı insanları aynı kefeye koyduğunu ve yoksulluğundan dolayı bu insanları damgaladığını iddia ettiklerini söyler. Wilson'a göre ise sorun kavramın kendisinden değil, gettoda yaşayan insanların karakter özelliklerine odaklanan muhafazakârların bu kavrama konuya gettoda yaşayanların sorunların toplumun geneli ile ilişkili olarak ele alabilecek olan liberallerden daha fazla ilgi duymuş olması, bunun sonucunda kavramın yaygınlaşmasında muhafazakârların etkili olmalarıdır (Wilson, 1987, s. 6-7). Burada karşılaşılan durum kavramın ilk kullanım biçiminden bağımsız olarak gelişen bir anlamlandırma sürecinin belirli bir ideolojik yaklaşımın kabulleri çerçevesinde şekillenmesidir. Wilson kavramın 1970'ler sonrası gettodaki yoksulluğun dönüşümünü anlamada değerli olduğunu ve bu- 
nun için kavramın ırkçı tonlardaki kullanımlarından farklı şekilde yeniden anlamlandırılması gerektiğini iddia eder (Wilson, 1987, s. 11, 18-19). Diğer bir deyişle amacı muhafazakârların kavram üzerindeki hâkimiyetini kırması yönünde liberalleri mobilize etmektir.

Wacquant'ın kendisini Amerikan siyasal hayatındaki liberal-muhafazakâr ikiliğinin üzerine yerleştirdiği ve yoksulluk yazınında her iki kesime seslenen çalışmaların da aynı amaca hizmet ettiğini düşündüğü görülmektedir. Wacquant'ın sınıf-altı kavramına olan eleştirilerinin haklı olup olmaması bir yana, ideolojik bir anlamlandırma mücadelesine bu derece açık olmasının bir kavramın analitik değerini düşürmesi kaçınılmazdır. Bununla birlikte her ülkede nüfusun geniş kısmını barındıran metropollerdeki gündelik hayata doğrudan etkisi olmasından dolayı ırkçılık, ayrımcılık ve yoksulluk eksenindeki tartışmalarda ön plana çıkan kavramların böyle bir mücadeleye sahne olması kaçınılmazdır. Ayrıca Wacquant kendisini Amerikan sosyolojisindeki farklı konumların üzerinde bir yere yerleştirmekle birlikte sınıf-altı kavramının etrafında dönüp durmak suretiyle, doğrudan veya dolaylı olarak, söz konusu mücadelenin bir parçası haline gelmektedir. Bu durumun kaçınılmazlığının da ötesinde Wacquant eleştirdiği akademik yayın dünyasından pek dışlanmış gibi görünmemekte, aksine sınıfaltını konu edinen, hatta başlığına taşıyan derleme kitaplarda ve akademik dergilerde ayn metinleri ufak tefek değişiklerle tekrar tekrar yayınlatarak adeta yerden yere vurduğu kavramın piyasasında bir tür çeşni olarak yerini almış gibi görünmektedir.

Wacquant'ın görüşlerine dair üzerinde durulması gereken ikinci sorun, yeni kentsel yoksulluğu anlamaya yönelik önerdiği çerçeve ve kavramların iddia ettiği hedefe hizmet etmesi anlamında kimi eksiklikler içermesidir. Wacquant'ın gelişmiş ekonomilerde hizmet sektörünün ön plana çıkması ve istihdam yapısındaki dönüşümle birlikte yeniden şekillenen kentsel yoksulluk tartışmalarındaki "yakınsama" tezine yönelik eleştirilerinin merkezinde sınıf-altı ve getto kavramlarının Avrupa bağlamında kullanılması yer almaktadır. Ancak Wacquant bu kavramları yerinden ç1kartıp "ileri marjinallik" kavramını koyarak belirli bir indirgeyici kavram seti yerine yeni bir indirgeyici kavram seti ortaya koymaktadır. Gans'ın da ifade ettiği gibi sosyal bilimcilerin geliştirdiklerin kavramların mülkiyetini elinde bulunduramayacakları (Gans, 1997, s. 506) göz önünde bulundurulduğunda, sınıf-altı kavramının işaret ettiğinden çok daha geniş bir grubu tanımlayan ileri marjinallik kavramının kentsel yoksulluğu ay- 
rımcllık ve damgalama amacıyla kullanılmayacak şekilde kavramsallaştırma çabasına nasıl hizmet edeceği belirsizdir. Konuya operasyonel olarak yaklaşılırsa, Wacquant'ın konu hakkındaki argümanları kavramın içeriğinde yer aldığını ifade ettiği yoksulluğun mekânsal yoğunlaşması durumuna dair açıklayıcı içerikten yoksundur. Bu durum Bourdieu'den mülhem mekânsal indirgemecilikten kaçma kaygısının (Wacquant, 2008/2010a, s. 19-20) uzantısı olarak Wacquant'ın 'mekân etkisini' bütünüyle göz ardı etmesinin bir sonucudur. Yoksulluk ve mekân ilişkisi, yoksul mahallelerde yaşayan kişilerin kendilerini yaşadıkları mahallenin diğer sakinlerinden farklı olarak görmelerinin çok daha ötesindedir. Wacquant konuyu "yukarıdan" ele alırken ise, özellikle ABD örneğinde sorunlu olan bir kabulle, merkezi bir devletin uygulamaya koyduğu belirli politikaların devletin diğer kademelerinde olduğu şekliyle uygulandığı bir yapıdan hareket etmektedir (Marwel, 2016, s. 1096). Neoliberalizm kavramı altında devletlerin işleyiş biçimindeki dönüşümde bir takım ortak eğilimlerin varlığı doğru olsa da bu eğilimlerin emek piyasalarından dışlanmaktan etnik ve ırksal ayrımcılığa kadar birçok farklı nedenle yoksulluğu deneyimleyen kesimlerin durumunu tek başına açıklayabileceğini iddia etmek, hiç olmazsa Wacquant'ın karşılaştırmalı bakışıyla örtüşmemektedir. Buradaki sorunun belli ölçüde Wacquant'ın kentleşme gibi disipliner s1nırların dışına çıkan bir çalışma konusunu genel olarak sosyoloji yazını çerçevesinde ele almasından ve kentleşme yazınına başka alanlardan yapılan katkılardan habersiz olmasa dahi bunlara değerlendirmelerinde s1nırlı yer vermesinden kaynaklandığı söylenebilir. 


\title{
Extended Abstract
}

\section{Conceptual Recalibration of the Debates on Urban Poverty: Wacquant and Advanced Marginality}

\author{
* \\ Anıl Mühürdaroğlu \\ Trakya University
}

De-industrialization process in advanced countries posed new challenges to urban policy makers in an age when the states were going through a process of restructuring and working classes were struggling to adapt to the new structure of employment. The very same process was changing the spaces of production through rehabilitation of the industrial areas of the previous era on the one hand and working class neighborhoods on the other. As it has been the case for sociological literature of the postwar era in general, urban sociology has dealt with this issue by applying the theoretical and conceptual tools which had been developed by American sociology which has a long tradition in poverty research and its relationship to spatial processes. As a result, impact of de-industrialization and the restructuring of the state on cities on both sides of the Atlantic is investigated via concepts like 'ghetto' and 'underclass'. These debates were backed by the widespread belief in the Americanization of European cities. Loic Wacquant criticizes this belief and offers a comparative perspective which he applied in his comparison between French banlieue and American ghetto. According to Wacquant, ghettos in American cities were a consequence of the inherent racism of housing market and public housing policy and the extent of concentration of a specific group in space cannot be observed in European cities. Therefore, it would be misleading to use this concept to describe neighborhoods with high level of unemployment in Europe. In his comparison between neighborhoods of poverty in the United States and France, Wacquant points to the ethnic heterogeneity of French banlieue contrary to the concentration of black population in American ghettos and the contrast between public policies in France which aim to mitigate urban poverty and the lack of state intervention in this regard in the United States. Underclass is another concept which is widely used in urbanization literature to define the new forms of poverty in the period of de-industrialization. The concept 
is heavily criticized by Wacquant. Although having been used originally to define the structural causes of urban poverty, the concept of underclass gained racist undertones especially with the popularity of the concept of 'culture of poverty' which linked the concentration of urban poor in ghetto neighborhoods to alleged cultural characteristics of black people. Wacquant points to two influential studies which use the concept of underclass. The first one is Truly Disadvantaged which was written by W. J. Wilson with whom Wacquant conducted a research and made some publications in the early years of his career. Wilson uses the concept in its classical, structural meaning and explains the high concentration of urban poor in black ghetto with the changing occupational structure. Wilson prefers using the concept for he believes that cultural aspect of poverty should not be overlooked. However, he considers culture as a dependent variable which, unlike what the concept of culture of poverty assumes, can change with economic conditions. The second study is Douglas Massey and Nancy Denton's American Apartheid which aims to display "the new ghetto culture" by using the concept of underclass. What separates Massey and Denton's study from Wilson's is their focus on the decisive impact of racist housing policies, actors of real estate market and even black politicians in the concentration of black in neighborhoods of poverty. This shift of emphasis leads to the denial of the economic determination which is assumed by Wilson. Wacquant claims that his approach to the relationship between urban poverty and American black ghetto is different from these two studies for it stresses the role of the state in the formation and transformation of ghetto -which was neglected, according to Wacquant, by Wilson who explains the issue with reference to blind market processes- and it detects the transformation of the poverty in ghettos by 1970s -which was neglected, again, according to Wacquant, by Massey and Denton whose mere stress on racism does not give us information about the changing nature of the poverty which is experienced in the black ghetto. Wacquant uses the concept of 'hyperghetto' to define the distinctive features of the black ghetto in the post-1970 period which lacks the integrated and communal nature of the ghetto of the Fordist period when black neighborhoods were not merely inhabited by the marginalized segment of the black population. The transition from the communal to the hyperghetto disrupted the relationship between people from various classes and produced neighborhoods which are inhabited by people who do not feel like they belong there. The hyperghetto is the product of the neolib- 
eral state policies in the United States which diminished the budget of poverty reduction programs on the one hand and engaged extensively in the construction of prisons where black inmates are disproportionately represented. According to Wacquant the penal policies and urban policies are connected. What he calls 'hyperincarceration' is backed by changing regulations on probation and parole which increased the surveillance of black population even outside of the prison and the concentration of blacks in ghettos contributes to this interconnected system which Wacquant defines as 'penal trap'. Wacquant's unending critique of the concept of underclass in all possible occasions ironically makes him a valuable asset in the academic market which concentrated around this concept. Although having a critical stance against the operation of knowledge production and publication policies in the scholarly world -a stance he inherited from his mentor, Pierre Bourdieu-, Wacquant becomes a part it by publishing his works again and again, sometimes with the same paragraphs with little or no tweaks, in many publications which has the concept of underclass in their heading. His exclusive focus on sociological studies and his disinterest in the related discussions in other disciplines like urban geography and public administration should also be regarded as a shortcoming of Wacquant's account considering the fact that urbanization is an issue which exceeds disciplinary boundaries.

\section{Kaynakça / References}

Allmendiger, P. ve Thomas, H. (Der.) (1998). Urban planning and the British new right. Londra: Routledge.

Anderson, E. (1999). Code of the Street: Decency, violence, and the moral life of the inner city. New York: W. W. Norton.

Aponte, R. (1990). Definitions of the underclass: A critical analysis. H. J. Gans (Der.), Sociology in America içinde (ss. 117-137). California: Sage.

Arl, A. ve Göker, E. (2014). Kent sosyolojisini Bourdieu ve Wacquant ile düşünmek. Cogito, 76, 121-138.

Bagnasco, A. ve LeGalés, P. (Der.) (2000). Cities in contemporary Europe. Cambridge: Cambridge University Press.

Barnekov, T., Boyle, R. ve Rich, D. (1989). Privatism and urban policy in Britain and the United States. Oxford: Oxford University Press.

Bauman, Z. ve May, T. (2001). Thinking sociologically. Oxford: Blackwell (Orijinal eserin yayın tarihi 1990). 
Bourdieu, P. (1998). Acts of resistance: Against the new myths of our time (R. Nice, Çev.). Cambridge: Polity Press.

Bourdieu, P. (2004). Science of science and reflexivity. (R. Nice Çev.). Chicago: The University of Chicago Press (Orijinal eserin yayın tarihi 2001).

Bourdieu, P. ve Wacquant L. (2001). NewLiberalSpeak: Notes on the new planetary vulgate. Radical Philosophy, 105, 2-5.

Burgess, E. W. (1967). Can neighborhood work have a scientific basis? R. E. Park, E. W. Burgess ve R. D. McKezie (Der.), The City. Chicago: The University of Chicago Press. (Orijinal eserin yayın tarihi 1925).

Castells, M. (1977). The urban question: A Marxist approach. (A. Sheridan, Çev.). Londra: Edward Arnold. (Orijinal eserin yayın tarihi 1972).

Duneier, M. (1999). Sidewalk. New York: Farrar, Straus \& Giroux.

Fainstein, S. S., Gordon, I. ve Harloe, M. (Der.) (1992). Divided cities: New York and London in the contemporary world. Oxford: Blackwell.

Flanagan, W. G. (1993). Contemporary urban sociology. New York: Cambridge University Press.

Gans, H. J. (1993). From 'Underclass' to 'undercaste': Some observations about the future of the postindustrtial economy and its major victims'. International Journal of Urban and Regional Research, 17 (3), 327-335.

Gans, H. J. (1994). Positive functions of the undeserving poor: Uses of underclass in America. Politics and Society, 22 (3), 269-283.

Gans, H. J. (1997). Uses and misuses of concepts in American social science research: Variations on Loic Wacquant's theme of 'Three pernicious premises in the study of the American ghetto'. International Journal of Urban and Regional Research, 21 (3), 504-507.

Hall, S. (1985). Signification, representation, ideology: Althusser and the poststructuralist debates. Critical Studies in Mass Communication, 2 (2), ss. 91-114.

Harloe, M. (1978). Introduction. M. Harloe (Der.), Captive cities: Studies in the political economy of cities and regions. New York: John Wiley \& Sons.

Hamnett, C. (2003). Unequal city: London in the global arena. Londra: Routledge.

Haussmann, H. ve Sackman, R. (1994). Changes in Berlin: The emergence of an underclass?. Built Envronment, 20 (3), 231-241.

Hirst, P. ve Zeitlin, J. (1991). Flexible specialization versus post-Fordism: Theory, evidence and policy implications. Economy and Society, 20 (1), 1-56.

Hunter, M. A. (2014). Ecologies, post-modern urbanisms, and symbolic economies: A comparative assessment of American urban sociology. Comparative Sociology, 13, 185-214.

Imrie, R. ve Thomas, H. (Der.) (1999). British urban policy: An evaluation of the urban development corporations. Londra: Sage.

Jessop, B. (1990). Regulation theories in retrospect and prospect. Economy and Society, 19 (2), 153-216. 
Kesteloot, C. (1994). Three levels of socio-spatial polarization in Brussels. Built Envronment, 20 (3), 204-217.

LeGalés, P. (2002) European cities: Social conflicts and governance. Oxford: Oxford University Press.

Lovering, J. (1990). Fordism's unknown successor: A comment on Scott's theory of flexible accumulation and the re-emergence of regional economies. International Journal of Urban and Regional Research, 14 (1), 159-174

Magnicol, J. (1987). In pursuit of the underclass. Journal of Social Policy, 16 (3), 293318.

Massey, D. S. ve Denton, N. A. (1993). American apartheid: Segregation and the making of the underclass. Cambridge, MA: Harvard University Press.

Marshall, M. G. (1999). Flexible specialization, supply-side institutionalism, and the nature of work systems'. Review of Social Economy, 57 (2), 199-219.

Marwel, N. P. (2016). Rethinking the state in urban outcasts. Urban Studies, 53 (6), 1095-1098.

Mingione, E. (1993). The new urban poverty and the underclass: Introduction. International Journal of Urban and Regional Research, 17 (3), 324-326.

Mollenkopf, J. H. ve Castells, M. (1991). Dual City: Restructuring New York. Rusell Sage Foundation, New York

Morris, M. (1989). From the culture of poverty to the underclass: An analysis of a shift in public language. The American Sociologist, 20 (2), 123-133.

Musterd, S. ve Ostendorf, W. (1994). Affluence, Access to jobs, and ethnicity in the Dutch welfare state: The case of Amsterdam. Built Envronment, 20 (3), 242253.

Newman, K. (1999). No shame in my game: The working poor in the inner city. New York: Russel Sage Foundation and Knopf.

Newman, P. ve Thornley, A. (1996). Urban planning in Europe. Londra: Routledge.

Oatley, N. (Der.) (1998). Cities, economic competition and urban policy. Londra: Paul Chapman.

Peterson, P. E. (1991-1992). The urban underclass and the poverty paradox. Political Science Quarterly, 106 (4), 617-637.

Robinson, F. ve Gregson, N. (1992). The underclass: A class apart? Critical Social Policy, 12 (34), 38-51.

Sassen, S. (1991). Global city: New York, London, Tokyo. Princeton: Princeton University Press.

Scott, A. J. (1988). Flexible production systems and regional development: The rise of new industrial spaces in North America and western Europe. International Journal of Urban and Regional Research, 12 (2), 171-186.

Silver, H. (1993). National conceptions of the new urban poverty: Social structural change in Britain, France and the United States. International Journal of Urban and Regional Research, 17 (3), 336-354. 
Smith, N. (1996). The new urban frontier: Gentrification and the revanchist city. Londra: Routledge.

Szelenyi, I. (Der.) (1984). Cities in recession: Critical response to the urban policies of the new right. Londra: Sage.

Tickell, A. ve Peck, J. A. (1992). Accumulation, regulation and the geographies of post-Fordism: Missing links in regulationist research. Progress in Human Geography, 16 (2), 190-218.

Wacquant, L. (1992). Toward a social praxeology: The structure and logic of Bourdieu's sociology. P. Bourdieu ve L. Wacquant, An invitation to reflexive sociology içinde (ss. 1-59). Chicago: The University of Chicago Press.

Wacquant, L. (1993). Urban outcasts: Stigma and division in the black American ghetto and the French urban periphery. International Journal of Urban and Regional Research, 17 (3), 366-383.

Wacquant, L. (1997). Three pernicious premises in the study of the American ghetto. International Journal of Urban and Regional Research, 21 (2), 341-353.

Wacquant, L. (2001). Deadly symbiosis: When ghetto and prison meet and mesh. Punishment and Society, 3 (1), ss. 95-133.

Wacquant, L. (2002a). The rise of advanced marginality: Notes on its nature and implications. P. Marcuse ve R.v. Kempen (Der.), Of states and cities: The partitioning of urban space içinde (ss. 221-239). New York: Oxford University Press.

Wacquant, L. (2002b). Scrutinizing the Street: Poverty, morality, and the pitfalls of urban ethnography. American Journal of Sociology, 107 (6), 1468-1532.

Wacquant, L. (2007). Territorial stigmatization in the age of advanced marginality. Thesis Eleven, 91, 66-77.

Wacquant, L. (2008). Ghettos and anti-ghettos: An anatomy of the new urban poverty. Thesis Eleven, 94, ss. 113-118.

Wacquant, L. (2009). Punishing the poor: The neoliberal government of social insecurity. Durham: Duke University Press.

Wacquant, L. (2010a). Kent paryaları: İleri marjinalliğin karşılaştırmalı sosyolojisi. (M. Doğan Çev.). İstanbul: Boğaziçi Üniversitesi Yayınları. (Orijinal eserin yayin tarihi 2008).

Wacquant, L. (2010b). Class, race and hyperincarceration in revanchist America. Daedalus, 139 (3), 74-90

Wacquant, L. ve Akçaoğlu, A. (2017). Practice and symbolic power in Bourdieu: The view from Berkeley. Journal of Classical Sociology, 17 (1), 55-69.

Wilson, W. J. (1987). The truly disadvantaged: The inner city, the underclass, and public policy. Chicago: The University of Chicago Press.

Yılmaz, B. (2008). Türkiye'de sinıf-altı: Nöbetleşe yoksulluktan müebbet yoksulluğa. Toplum ve Bilim, 113, 127-145. 
Anıl Mühürdaroğlu 2002 yılında Orta Doğu Teknik Üniversitesi (ODTÜ), Mimarlık Fakültesi, Şehir ve Bölge Planlama Bölümü'nden mezun oldu. Yüksek lisans derecesini 2005 yılında ODTÜ Kentleşme Politikaları ve Yerel Yönetimler Anabilim Dalı'ndan, doktora derecesini 2014 yılında ODTÜ Sosyoloji Bölümü'nden almıştır. Halen Trakya Üniversitesi, Edebiyat Fakültesi, İnsan ve Toplum Bilimleri Bölümü'nde öğretim üyesi olarak görev yapmaktadır.

Anıl Mühürdaroğlu is graduated from Department of City and Regional Planning, Faculty of Architecture, Middle East Technical University (METU) in 2002. He acquaired his MSc degree from the Urban Policy Planning and Local Governments graduate program at METU in 2005 and defended his PhD thesis in the Department of Sociology at METU in 2014. He works as an assistant professor in the Department of Humanities and Social Sciences in Faculty of Letters at Trakya University.

E-mail: anilmuhur@gmail.com 